\title{
Process Heating and Postannealing Effects on Microstructure and Hardness of the Sputtered Ni-P-Al Coatings
}

\author{
Yu-Ming Su, Chia-Che Wu, and Fan-Bean Wu \\ Department of Materials Science and Engineering, National United University, A2-344R, Lienda, Kung-Ching-Li, \\ Miaoli 36003, Taiwan \\ Correspondence should be addressed to Fan-Bean Wu, fbwu@nuu.edu.tw
}

Received 1 October 2010; Revised 31 December 2010; Accepted 5 January 2011

Academic Editor: David G. Morris

Copyright ( $(2011$ Yu-Ming Su et al. This is an open access article distributed under the Creative Commons Attribution License, which permits unrestricted use, distribution, and reproduction in any medium, provided the original work is properly cited.

Ternary Ni-P-Al alloy coating was fabricated by magnetron sputtering technique with a Ni-P/Al composite target source. The effects of thermal treatments, including deposition process heating and postannealing, on phase transformation phenomenon and related mechanical properties were investigated. The as-deposited coatings produced under process temperature below $475^{\circ} \mathrm{C}$ showed an amorphous/nanocrystalline microstructure. Significant crystallization of Ni matrix and precipitation of $\mathrm{Ni}_{x} \mathrm{P}_{y}$ and $\mathrm{Ni}_{p} \mathrm{Al}_{q}$ compounds were observed for the coatings manufactured under high sputtering temperatures above $500^{\circ} \mathrm{C}$. The amorphous Ni-P$\mathrm{Al}$ coatings were postannealed from 500 to $600^{\circ} \mathrm{C}$ in vacuum environment for comparison. The amorphous feature of the Ni-P-Al coating remained unchanged under a high annealing temperature of $550^{\circ} \mathrm{C}$, showing a superior thermal stability as compared to those fabricated under high process temperatures. Superior hardness was obtained for the post-annealed Ni-P-Al coatings due to volumetric constraint of crystallization and precipitation. On the other hand, the overaging phenomenon and subsequent degradation in hardness were found for the Ni-P-Al coatings fabricated under high-temperature deposition processes. The phase transformation mechanisms of the coatings through different thermal treatments were intensively discussed.

\section{Introduction}

Nickel-Phosphorus (Ni-P) coating is frequently adopted as a hard alloy coating due to its various merits, such as corrosion resistance, high hardness and toughness, and wear resistance [1-4]. Under adequate heat treatment, the binary $\mathrm{Ni}-\mathrm{P}$ can be strengthened by precipitation of intermetallic compounds, including $\mathrm{Ni}_{3} \mathrm{P}, \mathrm{Ni}_{5} \mathrm{P}_{2}, \mathrm{Ni}_{12} \mathrm{P}_{5}$, and $\mathrm{NiP}$ hard phases [5]. In order to further enhance its mechanical and thermal properties, the introduction of the third elements, including $\mathrm{Al}[6], \mathrm{Cr}[7], \mathrm{Cu}[8,9]$, and so forth, has been proposed. Especially for Ni-P-Al coatings, it has been pointed out that not only the crystallization temperature is increased but also the related mechanical properties are enhanced owing to the addition of Al [6]. Ni-Pbased coatings are usually fabricated through wet chemical methods, including electroless and electroplating techniques $[4,10]$. The codeposition of third element into Ni-P alloy through wet chemical procedures is sometimes complicated and not easy to control. Recently, the sputtering technique is successfully adopted to produce multicomponent Ni-Pbased alloy coatings with good composition control $[6,9$, $11,12]$. Since the Ni-P-based material is sensitive to thermal history, the process temperature during sputtering and postannealing are, thus, critical to the phase evolution and related mechanical property variation. In the present, study we focus on the temperature dependency of microstructure and correlated mechanical behaviors of the sputtering Ni$\mathrm{P}-\mathrm{Al}$ coatings. Thermal histories, including continuous heat treatment, process heating, and postannealing, are applied for comparison. The evolution in phase, microstructure, surface characteristics, and hardness with respect to the designed thermal procedures is intensively discussed.

\section{Experimental Procedures}

The ternary Ni-P-Al coatings were fabricated by radio frequency (r.f.) magnetron sputtering technique with a Ni-P/Al composite alloy target. The composite target was produced by an electrodeposited Ni-P thick film of approximately 
$200 \mu \mathrm{m}$ on a pure $\mathrm{Al}$ disc of $50.8 \mathrm{~mm}$ in diameter. Part of the Ni-P thick film was drilled off to expose the $\mathrm{Al}$ disc underneath, and, thus, a composite target providing $\mathrm{Ni}, \mathrm{P}$, and $\mathrm{Al}$ was ready for cosputtering. The silicon wafer and polished 420 stainless steel with $20 * 20 \mathrm{~mm}^{2}$ in surface area were employed as substrate materials. After loading the substrate on sample holder, the chamber was evacuated down to $8 \times 10^{-4} \mathrm{~Pa}$ followed by the inlet of $\mathrm{Ar}$ as the plasma source gas. The input power and targetto-substrate distance for all coatings were fixed at $100 \mathrm{~W}$ and $120 \mathrm{~mm}$, respectively. Substrate temperatures from room temperature to $600^{\circ} \mathrm{C}$ were carefully controlled. The coating thickness was approximately $1.0 \mu \mathrm{m}$, as shown in Figure 1(a). The cross-sectional and plane-view images of the Ni-P-Al coatings were carried out with a field-emission scanning electron microscope (FE-SEM, JXA-6700, JEOL, Japan). The composition of the Ni-P-Al coating was evaluated to be $\mathrm{Ni}_{74} \mathrm{P}_{14} \mathrm{Al}_{12}$ by the electron probe microanalysis, EPMA, system equipped on the FE-SEM. An X-ray diffractometer (XRD-6000, Shimadzu, Japan) was adopted to inspect the phase and microstructure of the Ni-P-Al coatings. In order to investigate the phase transformation phenomenon with respect to temperature, the continuous heating program was applied during in-situ X-ray diffraction. The temperature was raised from room temperature to $600^{\circ} \mathrm{C}$ with a fixed heating rate of $25^{\circ} \mathrm{C} / \mathrm{min}$. Conventional X-ray diffraction analysis was also carried out for phase identification for the coatings deposited under process heating and postannealing at 500,550 , and $600^{\circ} \mathrm{C}$ for comparison. Detailed surface morphology and roughness data were analyzed through an atomic force microscope (AFM, Solver P47H, NT-MDT, the Netherlands). The hardness of the Ni-P-Al coatings was evaluated with a nanoindentation tester (CSM, Nano Hardness Tester, Switzerland).

\section{Results and Discussion}

3.1. Phase Transformation. With the aid of the in-situ X-ray diffraction program, the instantaneous phase transformation phenomenon of the room temperature deposited Ni-P-Al coating was carried out. Figure 2 shows the diffraction patterns of the Ni-P-Al coatings heat-treated continuously at various temperature setpoints. Below $350^{\circ} \mathrm{C}$, a broadened peak with its highest intensity around $44.5^{\circ}$ was obtained and was recognized as a phase of amorphous $\mathrm{Ni}(111)$ matrix codeposited with $\mathrm{P}$ and $\mathrm{Al}$ [6]. When the temperature was increased between 400 and $450^{\circ} \mathrm{C}$, another broadened peak comprised of transient phases of $\mathrm{Ni}_{5} \mathrm{P}_{2}(600)$ and $\mathrm{Ni}_{12} \mathrm{P}_{5}(240)$ were observed. From 475 to $525^{\circ} \mathrm{C}$, the $\mathrm{Ni}(111)$ crystallized significantly with the development of various $\mathrm{Ni}_{x} \mathrm{P}_{y}$ compounds, such as $\mathrm{Ni}_{3} \mathrm{P}_{2} \mathrm{Ni}_{5} \mathrm{P}_{2}$, and $\mathrm{Ni}_{12} \mathrm{P}_{5}$. For example, the peaks around $36^{\circ}$ at $500-525^{\circ} \mathrm{C}$ in the XRD pattern in Figure 2, which referred to $\mathrm{Ni}_{3} \mathrm{Al}(110)$ and $\mathrm{Ni}_{3} \mathrm{P}(301)$, were not clearly resolved, implying a very early stage forming of the metastable $\mathrm{Ni}_{p} \mathrm{Al}_{q}$ and $\mathrm{Ni}_{x} \mathrm{P}_{y}$ phases. With further heating above $550^{\circ} \mathrm{C}$, the phases including $\mathrm{Ni}$, $\mathrm{Ni}_{3} \mathrm{Al}, \mathrm{Ni}_{3} \mathrm{Al}_{4}, \mathrm{Ni}_{3} \mathrm{P}, \mathrm{Ni}_{5} \mathrm{P}_{2}$, and $\mathrm{Ni}_{12} \mathrm{P}_{5}$ developed significantly. The transformation of Ni-P-Al coating with respect to temperature could be summarized as follows:

$$
\begin{aligned}
\mathrm{NiPAl}_{\text {amorphous/nanocrystalline }} & \longrightarrow \text { Heat treatment }<550^{\circ} \mathrm{C} \\
& \longrightarrow \mathrm{Ni}(\mathrm{Al})+\mathrm{Ni}_{x} \mathrm{P}_{y}, \\
\mathrm{NiPAl}_{\text {amorphous/nanocrystalline }} & \longrightarrow \text { Heat treatment } \geq 550^{\circ} \mathrm{C} \\
& \longrightarrow \mathrm{Ni}+\mathrm{Ni}_{x} \mathrm{P}_{y}+\mathrm{Ni}_{p} \mathrm{P}_{q} .
\end{aligned}
$$

Consequently, it was believed that the Ni-P-Al exhibited a thermal stability and transformed into final stage up to $550^{\circ} \mathrm{C}$ under continuous heating.

Since the Ni-P-Al coating was sensitive to thermal histories, it was essential to figure out the phase transformation phenomenon under various heat treatments. The phase identification of process heating and postannealing Ni-P-Al coatings under high temperatures from 500 to $600^{\circ} \mathrm{C}$ was carried out and illustrated in Figures 3 and 4, respectively. As deposited at $500^{\circ} \mathrm{C}$, an early stage of $\mathrm{Ni}(111)$ matrix and intermetallic compounds, including $\mathrm{Ni}_{3} \mathrm{P}(330), \mathrm{Ni}_{5} \mathrm{P}_{2}(600)$, and $\mathrm{Ni}_{12} \mathrm{P}_{5}(312)$, were observed. With increased temperature of $550^{\circ} \mathrm{C}$, the microstructure of the coating transformed into well-developed $\mathrm{Ni}$ crystalline matrix with $\mathrm{Ni}_{3} \mathrm{P}$ precipitates [5]. These phases developed further accompanied with superior X-ray intensities when the Ni-P-Al coating was deposited at $600^{\circ} \mathrm{C}$. The $\mathrm{Ni}_{3} \mathrm{Al}$ high-temperature phase was also discovered. During sputtering, the nucleation and growth of thin films could be intensified through substrate heating. It was believed that the high-temperature heating during deposition enhanced the growth of $\mathrm{Ni}$ and $\mathrm{Ni}-\mathrm{P}$ and Ni-Al intermetallic compounds as indicated in Figure 3. The trend in phase transition and development were thus comprehensible. On the other hand, the Ni-PAl coating showed a higher phase transition temperature under postannealing. As illustrated in Figure 4, the coatings annealed at 500 to $550^{\circ} \mathrm{C}$ both showed a broadened peak around $44.5^{\circ}$, representing a $\mathrm{Ni}$ amorphous/nanocrystalline phase. Slightly developed $\mathrm{Ni}_{x} \mathrm{P}_{y}$ phases were observed at $550^{\circ} \mathrm{C}$. The $\mathrm{Ni}_{x} \mathrm{P}_{y}$ developed further with $\mathrm{Ni}_{3} \mathrm{Al}$ phase at $600^{\circ} \mathrm{C}$ annealing. Nevertheless, the coating was still not fully crystalline; for that, the diffraction peaks for various intermetallic compounds around 40 to $45^{\circ}$ were not clearly recognized. It should be noted that considerable crystalline phases occurred for the Ni-P-Al coatings beyond $500^{\circ} \mathrm{C}$ in the previous study [6]. Since the addition amount of $\mathrm{Al}$ in Ni-P-Al in present study was much greater as compared to that in the previous work, a higher amorphous-tocrystalline transformation temperature for the coatings was expected.

3.2. Surface Characteristics. The phase transformation of Ni$\mathrm{P}-\mathrm{Al}$ coatings exhibited considerable dependency on surface characteristics. Table 1 indicates the roughness number, $\mathrm{Ra}$, of the Ni-P-Al coatings under process heating and postannealing treatments. The 500,550 , and $600^{\circ} \mathrm{C}$ deposited NiP-Al films exhibited Ra numbers of 4.5, 6.5, and $22.5 \mathrm{~nm}$, respectively. The $\mathrm{Ra}$ value of the room temperature asdeposited coating was evaluated as $0.4 \mathrm{~nm}$ for comparison. It should be noted that using process heating during sputtering deposition, the Ni-P-Al coatings tended to crystallize and 


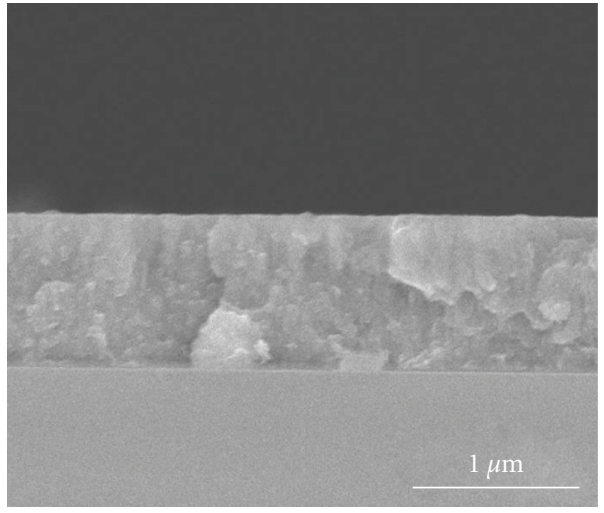

(a)

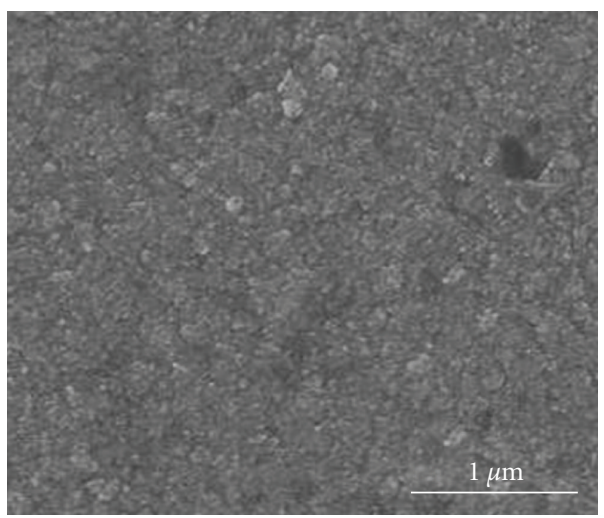

(c)

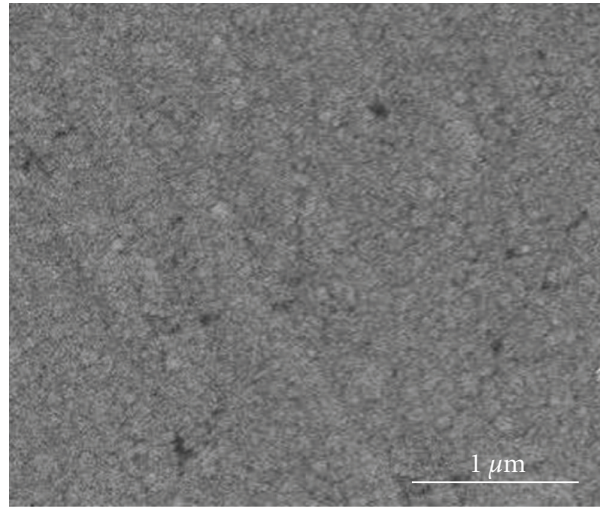

(b)

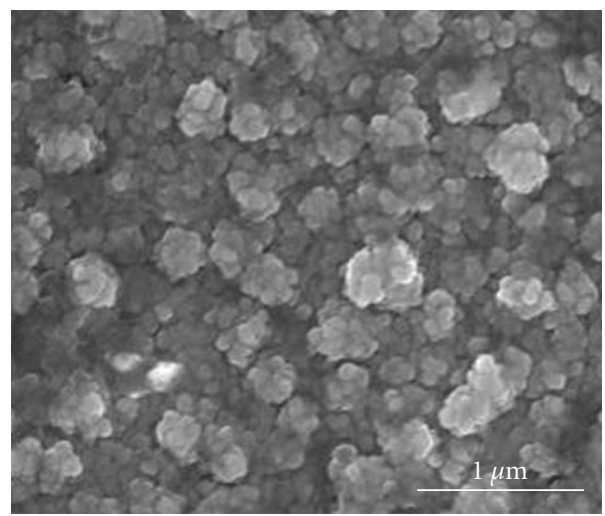

(d)

Figure 1: Scanning electron micrographs of (a) cross-sectional $475^{\circ} \mathrm{C}$ deposited, (b) plane-view as-deposited, (c) plane-view $475^{\circ} \mathrm{C}$ deposited, and (d) plane-view $550^{\circ} \mathrm{C}$ deposited Ni-P-Al coatings.

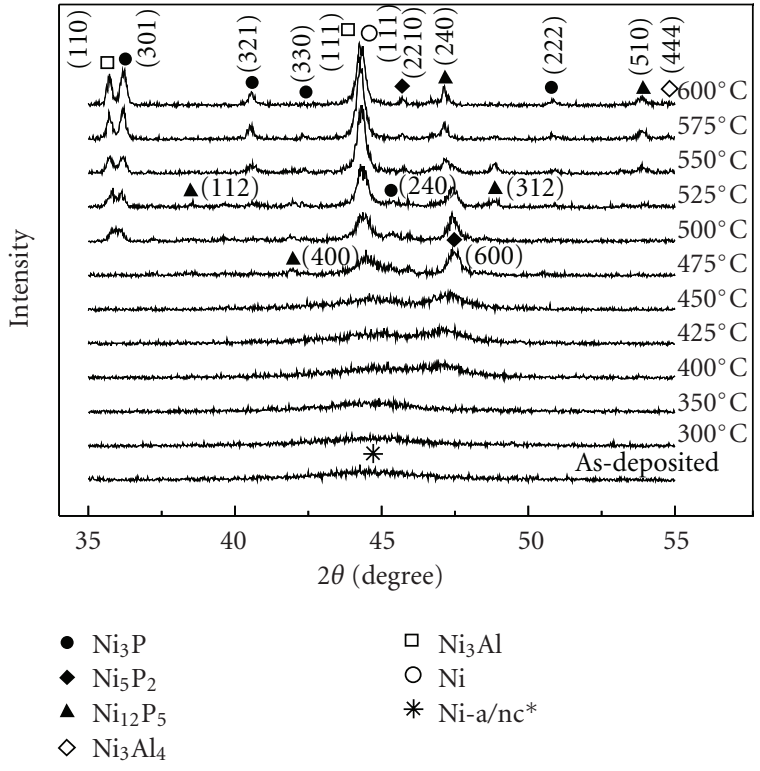

FIgURE 2: In-situ X-Ray diffraction patterns of the Ni-P-Al coating under continuous heating process. $(* \mathrm{a} / \mathrm{nc}$ : amorphous/nanocrystalline). precipitate on the instantaneous coating surface. Under such circumstances, $\mathrm{Ni}$ and related compounds nucleated and grew freely on the surface and caused a loose structure. It could be seen in Figures 1(b), 1(c), and 1(d) that the surface morphology changed significantly with respect to deposition temperature. The coating surface morphology was quite smooth as deposited below $475^{\circ} \mathrm{C}$, while large grains of several hundred $\mathrm{nm}$ in diameter were observed for the $550^{\circ} \mathrm{C}$ deposited Ni-P-Al coating. On the contrary, the postannealed coatings had a relatively lower Ra ranged from 0.5 to $3.2 \mathrm{~nm}$. This was because the $\mathrm{Ni}$ and related compounds formed under the confinement of coating thickness. There was no free space for nucleation and growth inside the coating volume. The difference could also be recognized from detailed surface morphology observation through atomic force microscopy in Figures 5 and 6. Significant granular morphology and larger $Z$-axis scale up to $200 \mathrm{~nm}$ were found for the coatings with process heating at $600^{\circ} \mathrm{C}$. Relatively smooth surface condition and reduced $Z$ range were discovered for the postannealed samples in comparison. Consequently, granular and rougher surface was found for the Ni-P-Al coating with high deposited temperatures. Due to volumetric constraint, the postannealed coatings showed 


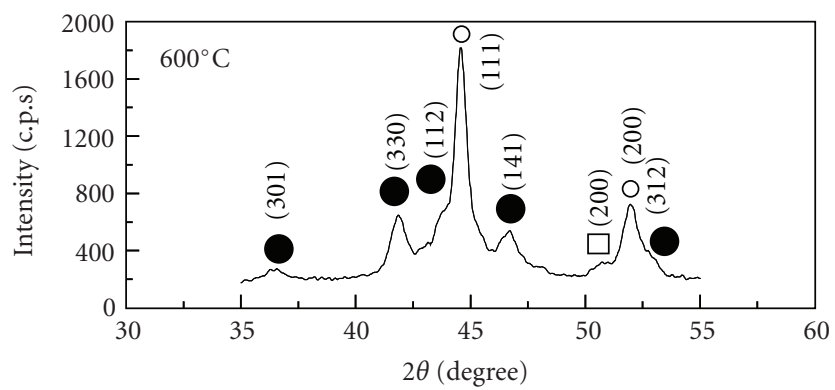

(a)

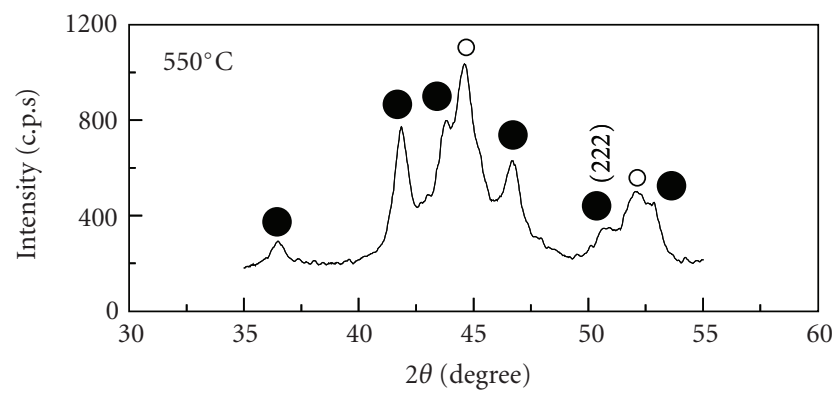

(b)

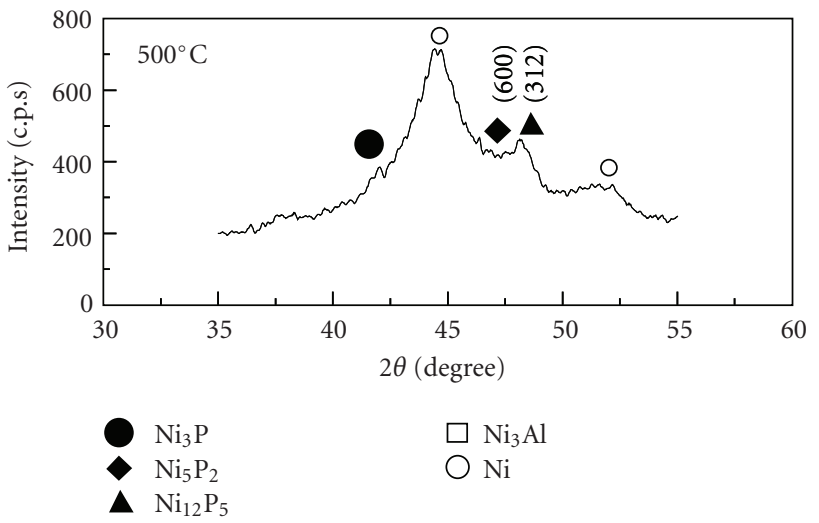

(c)

Figure 3: X-ray diffraction patterns of the Ni-P-Al coatings under various deposition process heating temperatures.

TABle 1: Surface roughness of the Ni-P-Al coatings under various process and postheat treatments.

\begin{tabular}{lccc}
\hline Treatments & \multicolumn{3}{c}{ Temperature $\left({ }^{\circ} \mathrm{C}\right)$} \\
& 500 & 550 & 600 \\
\hline PostAnnealing & 0.5 & 1.4 & 3.2 \\
Process Heating & 4.5 & 6.5 & 22.5 \\
\hline
\end{tabular}

${ }^{*}$ Ra unit: nm.

a smooth surface morphology and small Ra numbers as compared to those deposited under process heating.

3.3. Hardness. Figure 7 shows the hardness of the Ni-P-Al coatings after process heating and postannealing thermal histories. The hardness of the room temperature as-deposited $\mathrm{Ni}-\mathrm{P}-\mathrm{Al}$ coating was also evaluated to be $478 \pm 16 \mathrm{HV}$ for

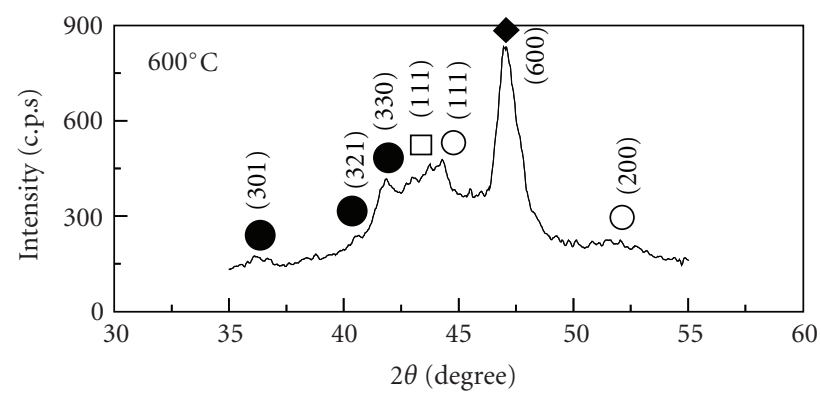

(a)

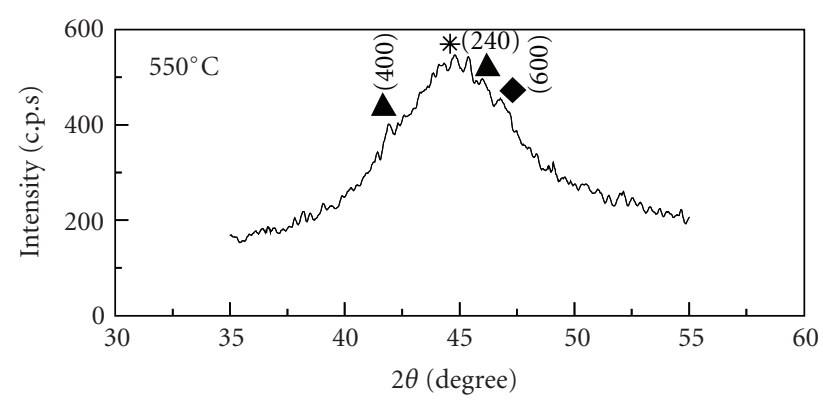

(b)

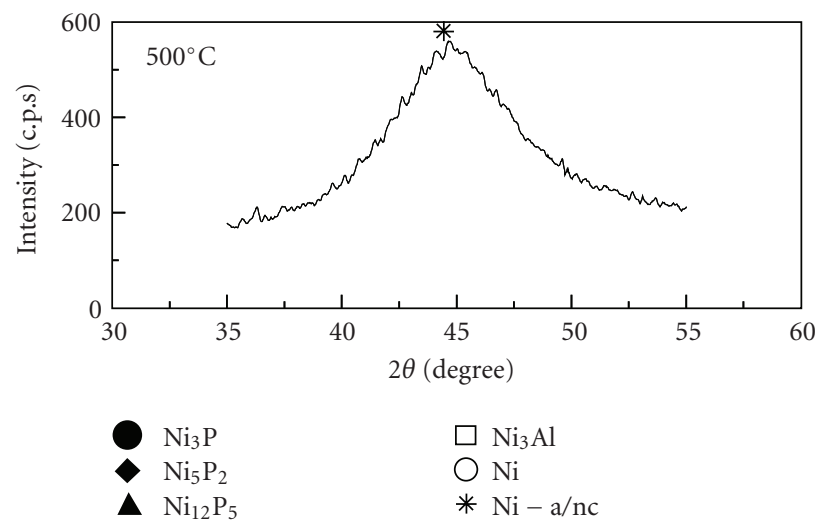

(c)

FIGURE 4: X-ray diffraction patterns of the Ni-P-Al coatings after postannealing process at various temperatures for $4 \mathrm{hrs}$.

reference. Under process heating at $500^{\circ} \mathrm{C}$, the $\mathrm{Ni}-\mathrm{P}-\mathrm{Al}$ coating exhibited a hardness of around $500 \mathrm{HV}$, which was comparable to Ni-P-based alloy coatings [7, 9, 13] and the room temperature deposited Ni-P-Al film in this study. The hardness slightly increased to approximately $590 \mathrm{HV}$ as the deposition temperature was raised to $550^{\circ} \mathrm{C}$ and then decreased to $410 \mathrm{HV}$ when $600^{\circ} \mathrm{C}$ substrate heating was applied. Such variation in hardness could be referred to the overaging phenomenon for most precipitation strengthening materials. It should be noted that in Figure 3, the Ni-P-Al coating approached to a fully crystalline state at $550^{\circ} \mathrm{C}$ and reached a well-defined final state of crystallization at $600^{\circ} \mathrm{C}$. Moreover, the enlarged grain size and loose microstructure found for the $550^{\circ} \mathrm{C}$ deposited $\mathrm{Ni}-\mathrm{P}-\mathrm{Al}$ coating in Figures $1(\mathrm{~d})$ and 5 were responsible for the degeneration in hardness. On the other hand, the hardness of the postannealed Ni-PAl coatings varied with an ever-increasing surface hardness 


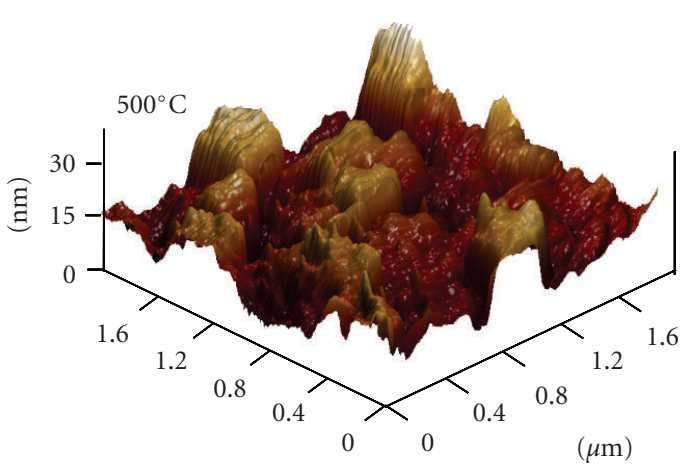

(a)

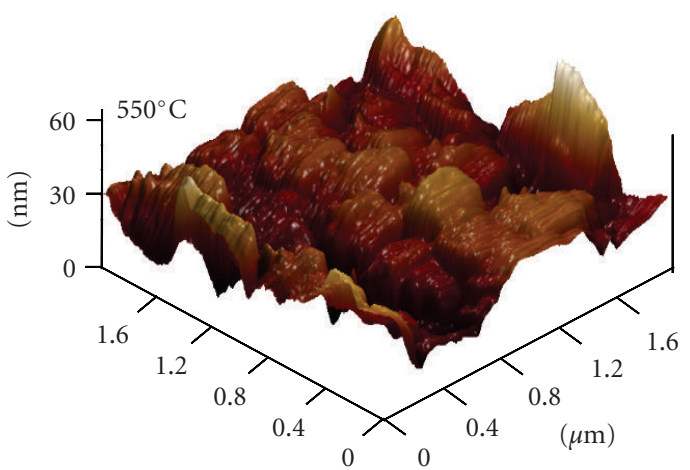

(b)

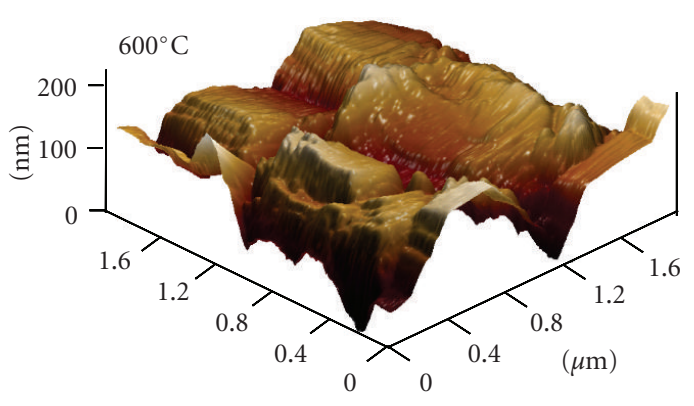

(c)

FIGURE 5: Surface morphology of the Ni-P-Al coatings under various deposition process heating temperatures.

from 500 to $600^{\circ} \mathrm{C}$. The hardness was firstly raised from 478 to $670 \mathrm{HV}$ at $500^{\circ} \mathrm{C}$. A further promotion to approximately $730 \mathrm{HV}$ was discovered as the annealing temperature went up to $550^{\circ} \mathrm{C}$. Unlike the trend for process heating specimens, the hardness was enhanced over $920 \mathrm{HV}$ under $600^{\circ} \mathrm{C}$ annealing. According to the phase transformation identification in Figure 4, early stage of transient $\mathrm{Ni}_{x} \mathrm{P}_{y}$ precipitations occurred at $550^{\circ} \mathrm{C}$ and led to a slight increase in hardness as compared to the room temperature and $500^{\circ} \mathrm{C}$ annealed Ni-P-Al coatings. As annealed at $600^{\circ} \mathrm{C}$, the further development in precipitates took place and the increase of hardness as a function of annealing temperature from 500 to $600^{\circ} \mathrm{C}$ was thus expected. Such phenomenon of annealing temperature effect on hardness of the Ni-P-Al sputtered

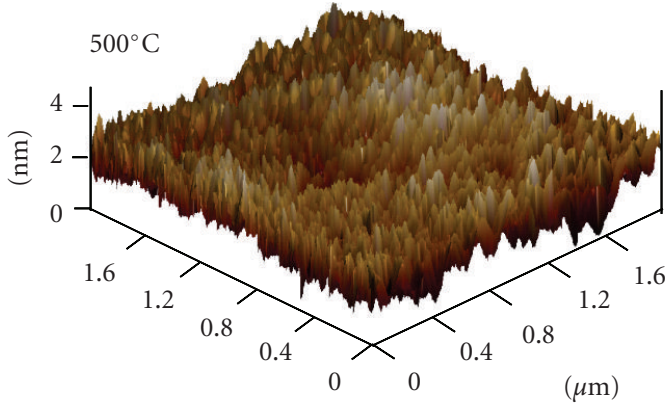

(a)

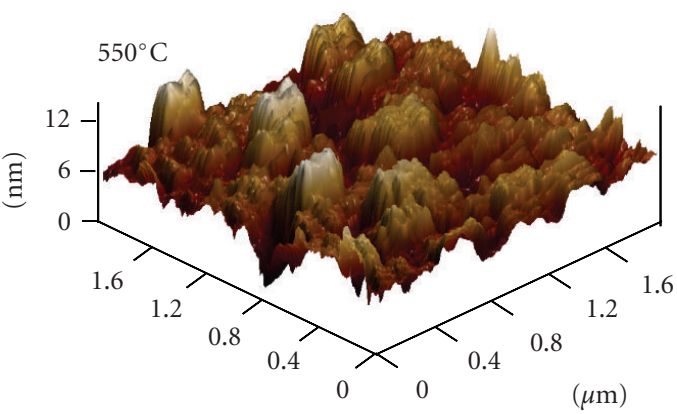

(b)

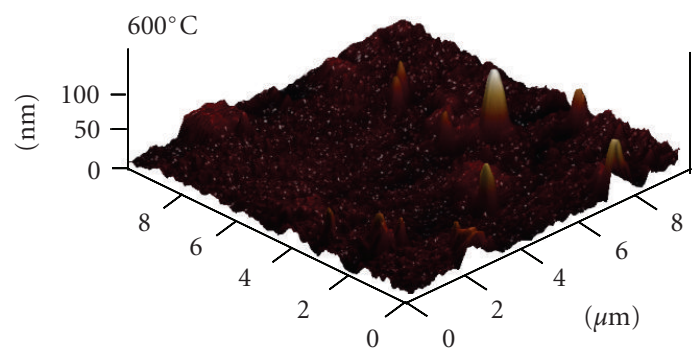

(c)

Figure 6: Surface morphology of the Ni-P-Al coatings after postannealing process at various temperatures for $4 \mathrm{hrs}$.

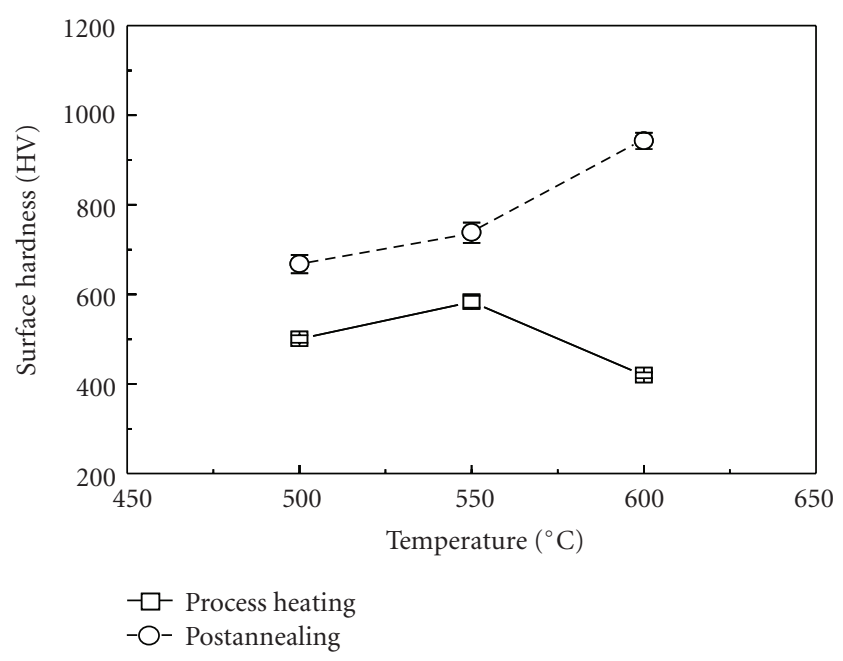

FIGURE 7: Surface hardness of the Ni-P-Al coatings under process heating and postannealing. 
coatings could be referred to a previous work [6]. It should be pointed out that all the postannealed coatings exhibited superior hardness than those under process heating. Due to volumetric constraint, the precipitation hardening was suppressed to higher temperature region. Even annealed at a higher temperature of $600^{\circ} \mathrm{C}$, the Ni-P-Al coating showed metastable phases of $\mathrm{Ni}_{x} \mathrm{P}_{y}$. As a result, the hardness kept increasing with respect to temperature. To sum up, the substrate heating during deposition of $\mathrm{Ni}-\mathrm{P}-\mathrm{Al}$ coatings forced the crystallization and precipitation at $550^{\circ} \mathrm{C}$ and resulted in an overaging phenomenon using process temperature of $600^{\circ} \mathrm{C}$. Meanwhile, the postannealed Ni-P-Al coatings exhibited a superior thermal stability and higher hardness of approximately $900 \mathrm{HV}$ up to $600^{\circ} \mathrm{C}$ owing to the suppression in precipitation by volumetric effect.

\section{Conclusions}

(1) The Ni-P-Al alloy coatings were successfully fabricated by sputtering technique with various thermal histories including process heating and postannealing. Through in-situ X-ray phase identification, amorphous to transient nanocrystalline phases were observed below $550^{\circ} \mathrm{C}$, while a fully transformed microstructure of Ni matrix with $\mathrm{Ni}_{x} \mathrm{P}_{y}$ and $\mathrm{Ni}_{p} \mathrm{Al}_{q}$ compounds was found above $550^{\circ} \mathrm{C}$ for the Ni-P-Al coatings. A thermal stability of $550^{\circ} \mathrm{C}$ was concluded for the ternary sputtering $\mathrm{Ni}-\mathrm{P}-\mathrm{Al}$ coatings.

(2) The process heating at 500 to $600^{\circ} \mathrm{C}$ during deposition provided sufficient energy and hastened the crystallization and precipitation. Since the film formation of the Ni-P-Al coating was accompanied by growth of crystallization and precipitation crystalline grains, the loose coating structure and rougher surface morphology were expected. Contrarily, under postannealing at higher temperatures of 550 to $600^{\circ} \mathrm{C}$, slower compound formation and smoother morphology of Ra less than $3.2 \mathrm{~nm}$ were obtained for the Ni-P-Al coatings owing to the volumetric constraint on nucleation and growth due to phase transformation.

(3) By postannealing process, a superior hardness up to $920 \mathrm{HV}$ could be deduced for the Ni-P-Al coatings as compared to that under process heating. The overaging phenomenon of the process heating films was attributed by the well developed crystallization of $\mathrm{Ni}_{x} \mathrm{P}_{y}$ and $\mathrm{Ni}_{p} \mathrm{Al}_{q}$ compounds at $550^{\circ} \mathrm{C}$. Using postannealing, the precipitation and crystallization were postponed toward high temperature. As a consequence, the Ni-P-Al coatings exhibited an ever increase hardness from 500 to $600^{\circ} \mathrm{C}$.

\section{Acknowledgment}

The financial support of this work from National Science Council in Taiwan under contract no. NSC-98-2221-E-239009-MY3 is highly appreciated.

\section{References}

[1] I. Garcia, J. Fransaer, and J. P. Celis, "Electrodeposition and sliding wear resistance of nickel composite coatings containing micron and submicron SiC particles," Surface and Coatings Technology, vol. 148, no. 2-3, pp. 171-178, 2001.

[2] L. F. Spencer, "Electroless nickel plating-a review_-3," Metal Finishing, vol. 72, no. 12, pp. 58-64, 1974.

[3] Y. Chiba, T. Omura, and H. Ichimura, "Wear resistance of arc ion-plated chromium nitride coatings," Journal of Materials Research, vol. 8, no. 5, pp. 1109-1115, 1993.

[4] K. L. Lin and J. W. Hwang, "Effect of thiourea and lead acetate on the deposition of electroless nickel," Materials Chemistry and Physics, vol. 76, no. 2, pp. 204-211, 2002.

[5] K. G. Keong, W. Sha, and S. Malinov, "Crystallisation kinetics and phase transformation behaviour of electroless nickelphosphorus deposits with high phosphorus content," Journal of Alloys and Compounds, vol. 334, no. 1-2, pp. 192-199, 2002.

[6] F. B. Wu, S. K. Tien, Y. Z. Tsai, and J. G. Duh, "Phase transformation and hardness of the Ni-P-Al ternary coatings under thermal annealing," Thin Solid Films, vol. 494, no. 1-2, pp. 151-154, 2006.

[7] W.-Y. Chen and J.-G. Duh, "Thermal stability of sputtered $\mathrm{Ni}-\mathrm{P}$ and Ni-P-Cr coatings during cycling test and annealing treatment," Surface and Coatings Technology, vol. 177-178, pp. 222-226, 2004.

[8] S. Armyanov, O. Steenhaut, N. Krasteva et al., "Auger electron spectroscopy element profiles and interface with substrates of electroless deposited ternary alloys," Journal of the Electrochemical Society, vol. 143, no. 11, pp. 3692-3698, 1996.

[9] Y. C. Chang, J. G. Duh, and Y. I. Chen, "Fabrication and crystallization behaviors of sputtered $\mathrm{Ni}-\mathrm{Cu}-\mathrm{P}$ films on tool steel," Surface and Coatings Technology, vol. 139, no. 2-3, pp. 233-243, 2001.

[10] P. Pouderoux, I. Chassaing, J. P. Bonino, and A. Rousset, "Plating of nickel-phosphorus multilayer alloys: current pulse effects on the microstructural and mechanical properties," Surface and Coatings Technology, vol. 45, no. 1-3, pp. 161-170, 1991.

[11] F.-B. Wu, S.-K. Tien, J.-G. Duh, and J.-H. Wang, "Surface characteristics of electroless and sputtered Ni-P-W alloy coatings," Surface and Coatings Technology, vol. 166, no. 1, pp. 60-66, 2003.

[12] F. B. Wu, Y. M. Su, Y. Z. Tsai, and J. G. Duh, "Fabrication and characterization of the Ni-P-Al-W multicomponent coatings," Surface and Coatings Technology, vol. 202, no. 4-7, pp. 762767, 2007.

[13] F. B. Wu and J. G. Duh, "Mechanical characterization of NiP-based ternary coatings by RF magnetron sputtering," Thin Solid Films, vol. 441, no. 1-2, pp. 165-171, 2003. 

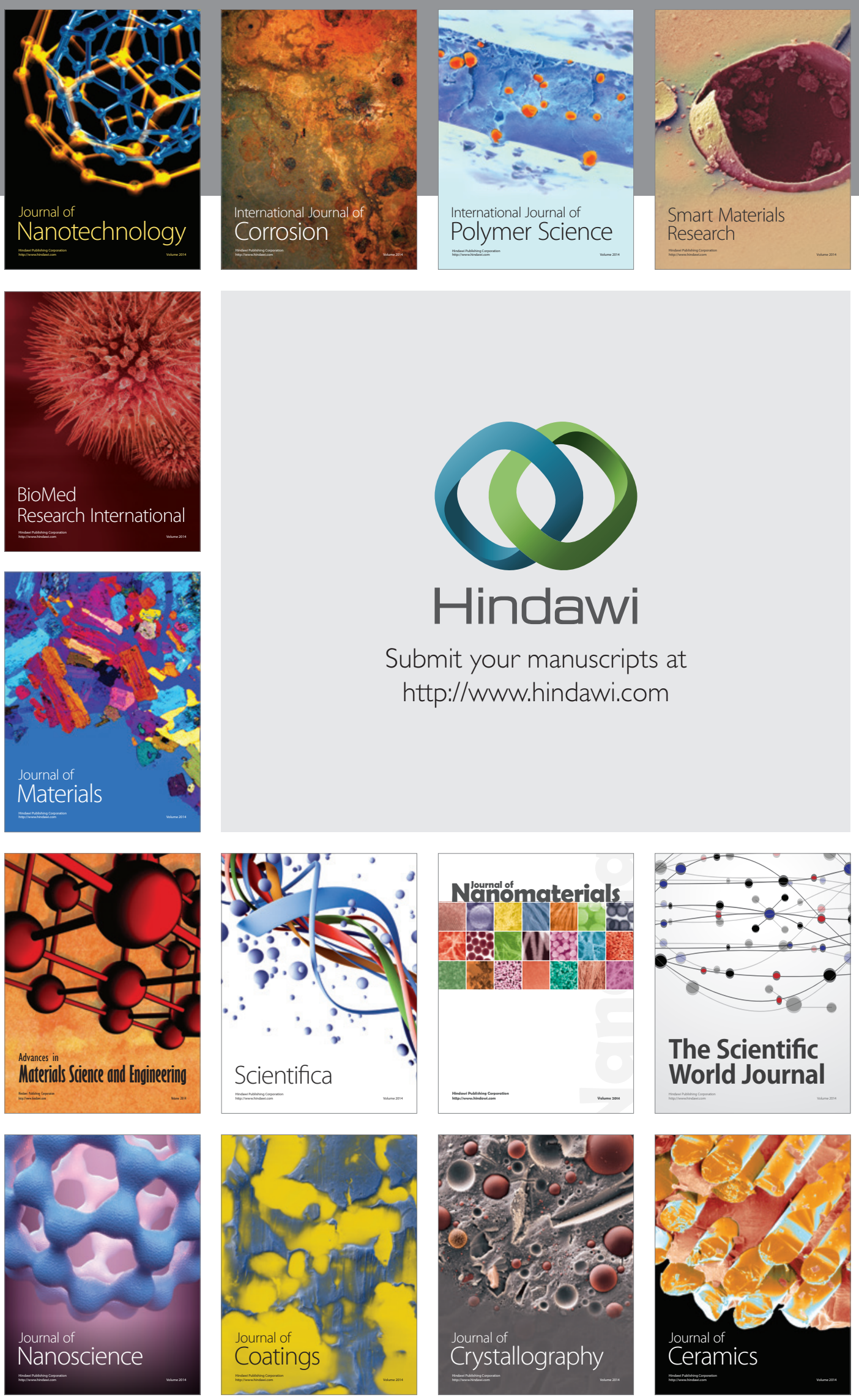

The Scientific World Journal

Submit your manuscripts at

http://www.hindawi.com

\section{World Journal}

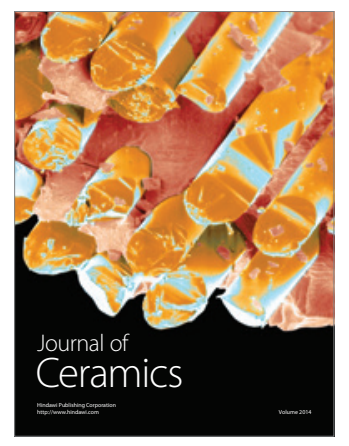

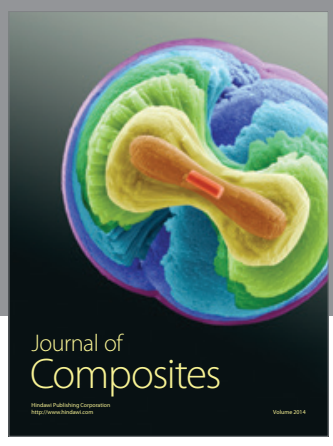
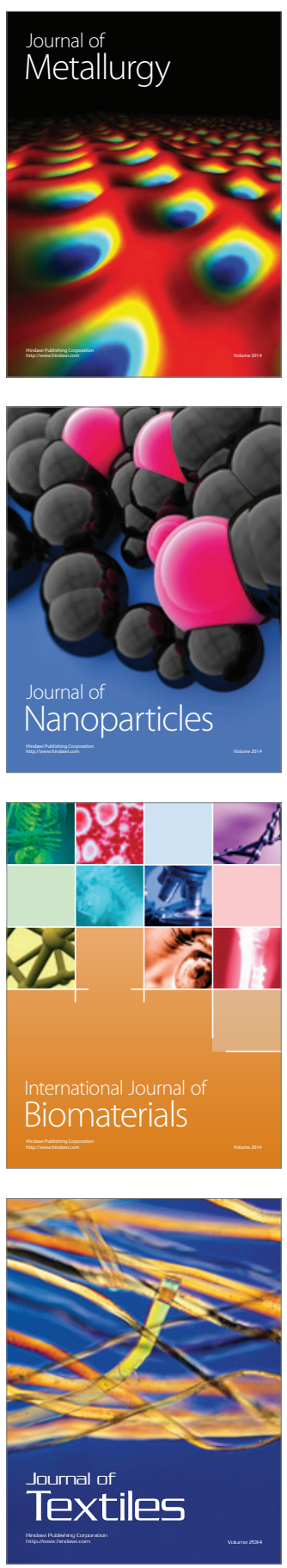